\title{
DNR A Decisão de Não Reanimar
}

\section{DNR (Do Not Resuscitate)}

António H. Carneiro (https://orcid.org/0000-0002-0774-6863), Rui Carneiro (https://orcid.org/0000-0002-0213-2504)

\section{Resumo:}

A Decisão de Não Reanimar (DNR) é uma prescrição médica justificada em situações de fim de vida / morte iminente na qual se estabelece que, num doente bem identificado, não deve ser iniciada, nem tentada a reanimação cardiorrespiratória em caso de paragem cardiorrespiratória acontecida ou iminente. A decisão deve ser deliberada com o doente e pessoas significativas e tem a intenção de respeitar os desejos da pessoa e minorar o seu sofrimento. A DNR aplica-se a situações de paragem cardiorrespiratória deve ser integrada num plano individual e integrado de cuidados ajustado à pessoa, à sua circunstância e ao momento.

Palavras-chave: Diretivas Antecipadas de Vontade; Decisão de Não Reanimar.
Abstract:

Do Not Resuscitate (DNR) is a medical order in end of life I imminent death situation in which it is established that, in a clearly identified patient, resuscitation should not be implemented (or even tried) in case of cardiac / respiratory arrest occurring or impending. Decision should be supported by a deliberative process, respecting wishes and values of the person and minimizing her/his suffering. DNR applies exclusively to cardiorespiratory arrest situations and when prescribed should be articulated with an individual and integrate care plan, adjusted to that person, to her / his circumstance and to the moment in which it is established.

Keywords: Advance Will Directives; Decision not to reanimate.

\section{Introdução}

Paragem cardiorrespiratória (PCR) significa paragem da circulação resultante da cessação da função de bomba do coração, seguida ou precedida de paragem respiratória. ${ }^{1}$ Estas duas falências associadas provocam hipóxia e hipoperfusão de todos os órgãos, com relevo para o córtex cerebral. Se a PCR não for revertida em minutos, é fatal.

\section{Enquadramento}

A paragem da respiração e/ou da circulação equivalia, até à década de 60 do século XX, a morte. Contudo, as parteiras reanimam recém-nascidos em paragem respiratória, há séculos, soprando ar para os seus pulmões. No século XVIII demonstrou-se que era possível reverter paragens respiratórias insuflando ar para os pulmões de modelos animais e depois humanos. ${ }^{2}$ No século XX conseguiram-se repor em funcionamento corações parados em ritmos desfibrilháveis. ${ }^{2}$ Em 1960 Kouwenhoven et a/ ${ }^{\beta}$ demonstram que se pode preservar a circulação em situação de PCR com compressões torácicas externas eficazes. Na mesma altura produzem-se desfibrilhadores cardíacos externos portáteis capazes de reverter disritmias em ritmos desfibrilháveis, que podiam ser levados ao local onde ocorreu a PCR. ${ }^{2,3}$ A associação destas três técnicas permite recuperar pessoas em PCR e é a base dos algoritmos

Departamento de Medicina, UCl e Urgência, Hospital da Luz Arrábida, Vila Nova de Gaia, Portugal

https://revista.spmi.pt - DOI: 10.24950/P.Vista/277/19/2/2020 da reanimação cardiorrespiratória (RCR). A PCR deixou de ser igual a morte. A prática da RCR generalizou-se à comunidade médica, a outros profissionais de saúde e a leigos como forma de salvar vidas. ${ }^{4}$ A maioria dos hospitais e comunidades dos países desenvolvidos têm modelos de resposta à emergência que iniciam, de imediato, a RCR em caso de PCR iminente ou acontecida. É o estado da arte em vítimas de PCR, com indicação para serem reanimadas. ${ }^{4}$

\section{REANIMAÇÃO CARDIORRESPIRATÓRIA: PRINCÍPIOS TERAPÊUTICOS}

Para que a RCR seja eficaz (restabelecimento da circulação e da respiração autónomas), a resposta tem de ser imediata e eficaz, ${ }^{4}$ o que exige modelos de resposta à emergência qualificados e com profissionais bem treinados nas três intervenções que, comprovadamente, salvam vidas em caso de PCR:

1. reconhecimento imediato, pedido de ajuda e chegada da ajuda em tempo oportuno, ${ }^{4}$

2. manter a circulação com compressões torácicas eficazes, de imediato ${ }^{4} e$

3. desfibrilhar, de imediato, os ritmos desfibrilháveis. ${ }^{4}$

Quando estes preceitos são corretamente executados a taxa de recuperação pode chegar aos $74 \%$ se a PCR foi súbita, testemunhada, em fibrilhação ventricular e desfibrilhada nos primeiros 3 minutos pós PCR. ${ }^{5}$ Contudo, no mesmo cenário (casinos), quando a desfibrilhação foi efetuada mais de 3 minutos pós PCR, ${ }^{5}$ a taxa de recuperação baixou para $49 \% .^{5}$ Fora deste contexto excecional, a maioria das pessoas que 
sofre PCR não sobrevive e as tentativas de reanimação falham em 70\%-98\% dos casos. ${ }^{6}$ Apesar da baixa eficácia, a RCR é a única possibilidade de impedir a morte imediata em caso de PCR e permite estabelecer uma ponte para tratamento definitivo em situações médicas agudas como enfarte agudo do miocárdio, afogamento e eletrocussão. ${ }^{4}$ No entanto, em contexto de comorbilidades múltiplas e na presença de doença(s) crónica(s) em estádio avançado raramente se mostra uma opção eficaz para recuperar qualidade de vida próxima da que existia antes da PCR. ${ }^{6-8}$ As lesões cerebrais resultantes da hipoperfusão / hipóxia pós PCR são tanto maiores quanto mais deteriorado estiver o cérebro, quanto pior for o estado da circulação cerebral e quanto maior for o tempo em PCR ${ }^{4,6}$ Por isso, resumir a indicação para RCR apenas à capacidade de repor o coração em funcionamento é uma visão estreita e incorreta. ${ }^{6-8}$ Há muitas vítimas de PCR em quem é possível restabelecer a circulação e a respiração eficazes, mas que ficam com graves lesões cerebrais, apesar de serem capazes de manter, durante algum tempo, as funções básicas do tronco cerebral. ${ }^{6,7}$ A probabilidade de alta hospitalar em caso de PCR é de 10\%-20\% em caso de PCR intra-hospitalar e 5\%-10\% em caso de PCR extra hospitalar.9 A identificação criteriosa de doentes que não devem ser candidatos a manobras de RCR é tão importante como a organização e treino das competências em RCR e é responsabilidade de todos os médicos que lidam com doentes em risco elevado de PCR.

Entendido desta forma, a RCR é um tratamento com indicações, contraindicações, posologia, benefícios previsíveis e riscos.

\section{DECISÃO DE NÃO REANIMAR: CONCEITO}

A Decisão de Não Reanimar (DNR) é uma prescrição médica para que se não inicie um tratamento concreto: a RCR. O acrónimo DNTR reforça a noção de que nem sequer se deve Tentar Reanimar.

A DNR é uma prescrição médica, porque se fundamenta no conhecimento do diagnóstico e do prognóstico, que são responsabilidades médicas. ${ }^{1}$ Deve ser assumida por um ou mais médicos, quando a informação existente é adequada e suficiente. A DNR tem em consideração os desejos expressos pelo doente, sobre o seu fim de vida e a situação clínica na altura em que a decisão é assumida.,10 Por definição a DNR aplica-se a pessoas e não a doenças. ${ }^{7,10} \mathrm{O}$ conceito de DNR foi introduzido para proteger pessoas em fim de vida de intervenções com risco de complicações e baixa ou nula probabilidade de sucesso. A DNR tem por objetivo evitar o prolongamento do sofrimento e das sequelas da PCR (neurológicas) que agravam o estado prévio do doente, $, 6,8-10$ mesmo que o retorno da circulação e da respiração sejam provisoriamente conseguidos.

A DNR não é uma ordem - é uma prescrição médica, fruto de uma decisão que deve ser baseada num processo de deliberação, ${ }^{1}$ pelo que, em português, o termo "Ordem" de Não Reanimar é um termo incorreto. ${ }^{1}$ A transposição literal do termo inglês "order", que na sua língua original significa prescrição, é desajustada à semântica portuguesa e ao conceito de DNR. ${ }^{1}$

A DNR só se aplica às manobras de reanimação e não se aplica a mais nenhum tratamento. ${ }^{1}$ Para cada doente em

Tabela 1: Resumo das Características da Reanimação Cardiorrespiratória.

\begin{tabular}{|c|c|}
\hline Designação do Tratamento & Reanimação Cardiorrespiratória \\
\hline Indicação terapêutica & Situações de Paragem Cardiorrespiratória \\
\hline Mecanismo de Ação & Mantém circulação sanguínea, a oxigenação tecidular e reiniciar ritmo cardíaco eficaz \\
\hline Posologia & $\begin{array}{l}\text { Proteção da via aérea } \\
\text { Ventilação e oxigenação } \\
\text { Compressões torácicas } \\
\text { Desfibrilação } \\
\text { Uso de fármacos em contexto próprio }\end{array}$ \\
\hline Eficácia & $\begin{array}{l}\text { Retorno de Circulação Espontânea: 2\%-30\% } \\
\text { Probabilidade (aproximada) de alta hospitalar cada } 100 \text { doentes que receberam RCR } \\
\text { - Enfarte agudo miocárdio: } 15 \\
\text { - Lesão renal grave: } 5 \\
\text { - Cancro: } 2 \\
\text { - Insuficiência cardíaca: } 2 \\
\text { - Sépsis: } 1\end{array}$ \\
\hline Qualidade da Evidência (GRADE) & Muito baixa ou baixa \\
\hline Efeitos Laterais & $\begin{array}{l}\text { Fraturas costais } \\
\text { Lesão pulmonar } \\
\text { Sequelas neurológicas } \\
\text { Ativação inapropriada de recursos } \\
\text { Prolongamento de sofrimento } \\
\text { Morte indigna }\end{array}$ \\
\hline Contra-indicação & Doentes com DNR \\
\hline
\end{tabular}


quem foi estabelecida a DNR é necessário estabelecer um plano ajustado às suas necessidades, independentemente do tempo que sobreviva. ${ }^{7,9,11,12}$ Nele se inclui o controlo de sintomas, as intervenções justificadas pelo desejo da pessoa, da sua circunstância e da sua doença $a^{9,11}$ que, caso a caso, podem incluir indicação para antibioterapia, transfusões, suporte ventilatório, cardiocirculatório, renal ou outra função vital apesar da DNR. A DNR não pode ser confundida com abandono do doente e não implica a suspensão de qualquer medida de suporte avançado de funções vitais (SAFV). ${ }^{15}$ Manter, incrementar, não iniciar ou suspender qualquer outro tratamento implica prescrição especifica e explicita para esse mesmo fim. ${ }^{11,12,15}$

\section{A DNR PODE SER REVOGADA SE AS CIRCUNSTÂNCIAS SE ALTERAREM E O JUSTIFICAREM}

A DNR tem por objetivo não instituir procedimentos que se não destinam a aliviar o sofrimento e que podem prolongar e/ou agravar o sofrimento. Contudo, nos casos em que é necessário fazer cirurgia, anestesia, procedimentos invasivos (descompressão cirúrgica de oclusão intestinal, traqueostomia, gastrostomia de alimentação, ...), ${ }^{14}$ justifica-se que a DNR seja suspensa no período peri procedimentos, com a intenção de resolver eventuais complicações associadas ao procedimento. No mesmo entendimento em caso de incidente agudo reversível: sufocação com alimentos, anafilaxia, pneumotórax iatrogénico, .... devem-se instituir os tratamentos ajustados e proporcionados à situação.

\section{COMO ESTABELECER A DNR: DELIBERAÇÃO E DECISÃO}

Por definição em caso de PCR acontecida ou iminente a RCR deve ser iniciada de imediato, o que não exige consentimento do doente ou da família. Se a DNR foi estabelecida, durante o internamento ou por Diretiva Antecipada de Vontade (consultar possibilidade de existir Testamento Vital registado no RENTEV) a RCR não deve ser iniciada, nem tentada. Em circunstâncias em que não há informação suficiente para a tomada de decisão, a RCR deve ser iniciada de imediato, enquanto se procura obter a informação necessária. Se a informação coligida revelar que a RCR não devia ter sido iniciada, os tratamentos inapropriados devem ser suspensos, a RCR abortada e instituídos procedimentos que proporcionem uma morte o mais tranquila possível.

Excetuando estas circunstâncias inesperadas e emergentes, na maior parte das situações, o tempo até à DNR é o que for necessário para conhecer os factos e os valores referentes a cada pessoa concreta no momento e circunstância em que a decisão é tomada. A decisão deve inscrever-se num percurso de acompanhamento do doente e sua família e é desejável que faça parte do plano individual e integrado de cuidados (PIIC). ${ }^{11,13,14}$ As boas práticas estabelecem que todos os doentes com doença avançada devem ter um plano individual e integrado de cuidados.
A DNR (tal como todas as decisões terapêuticas) deve ser fundamentada num processo de deliberação ${ }^{13,14}$ no qual o médico responsável deve ter em consideração:

1. se está de posse dos factos clínicos relevantes para assumir a DNR, quando indicada;

2. se a natureza, evolução e prognóstico da(s) doença(s), prefiguram uma situação clínica em que doente não beneficia de RCR, razão pela qual as intervenções que resultem em prolongamento do sofrimento estão contraindicadas, ex.: se a morte é expectável a curto prazo não há indicação para reanimar em caso de PCR;

3. se o doente, quando em pleno uso das suas faculdades, na ausência de patologia psiquiátrica e adequadamente informado, explicitou que não pretendia ser reanimado em caso de PCR;

4. se o doente, pessoas significativas e equipa de profissionais de saúde tiveram oportunidade para expressar o que pensam sobre o assunto legitimando e fundamentando a decisão;

Na maioria das situações a morte é um cenário previsível, que se anuncia pela progressão da doença de base, com redução da resposta aos tratamentos, tanto nos cenários de doença aguda como crónica progressiva. Neste último contexto, o aumento da fragilidade e da dependência é um indicador prognóstico determinante. Os médicos têm muitas vezes dificuldade em estabelecer um prognóstico, mas há instrumentos capazes de auxiliar a identificar esses cenários de fim de vida. O Gold Standard Framework é um dos instrumentos que auxilia o clínico a tomar consciência da condição de fim de vida. ${ }^{12}$ Nesse conceito assume-se que se em resposta à pergunta: "ficaria surpreendido se este doente morresse nos próximos 12 meses", a resposta for "não ficaria surpreendido" deve-se assumir que esse doente está em situação de fim de vida. O objetivo desta estratégia é identificar e antecipar necessidades para elaborar um plano de cuidados centrado na pessoa (individual), que tenha em consideração as suas diversas necessidades (integrado) e que inclua as prescrições justificadas e desejáveis e as que são injustificados e prejudiciais. ${ }^{7-11}$ A construção desse plano deve respeitar os desejos e diretivas expressas pelo doente sobre o seu futuro, incluindo as que tiverem sido expressas sobre o seu fim de vida. ${ }^{11}$ Como sustentam Brenda Nevidjon e Deborah Mayer "Death is not an option, how you die is". ${ }^{10}$

Em contexto de cuidados intensivos, por definição a maioria das mortes são antecipáveis, pelo que as decisões de suspender ou não iniciar SAFV, nas quais se inclui a DNR devem ser a regra nas situações em que a morte é antecipável. ${ }^{15}$

A aquisição, explicação e ponderação destes elementos leva tempo e é variável de caso para caso. A esse tempo, durante o qual todos aqueles a quem a decisão diz respeito são considerados agentes morais válidos e por isso são solicitados a dar razões para os seus pontos de vista e a ouvir as 
razões dos outros, chama Diego Gracia o tempo da deliberação. ${ }^{13,14} \mathrm{O}$ objetivo da deliberação não é chegar a consenso, mas sim enriquecer a perspetiva individual através do conhecimento do ponto de vista do outro e desta forma aumentar a maturidade da decisão. Em muitos casos, no final do processo deliberativo, os participantes têm opções distintas, mas o confronto de opiniões modificou a perceção que cada um tem desse(s) problema(s). O objetivo do processo deliberativo ${ }^{14}$ é que todos saibam o que todos pensam sobre o que há que decidir. As nossas decisões morais são influenciadas por sentimentos, valores e crenças pelo que não podem ser inteiramente racionais. A deliberação é o principal instrumento para alcançar decisões razoáveis, sensatas e prudentes, porque nos obriga a ter os outros em consideração, a respeitar as suas convicções e solicitaos para que exponham as razões que sustentam os seus próprios pontos de vista. ${ }^{11,13,14}$

\section{PERSPETIVA LEGAL SOBRE A DNR}

Os procedimentos praticados na RCR (compressões torácicas com risco de fraturas costais e do esterno, entubações traqueais ou laríngeas, ventilação com pressões positivas, cardioversões / desfibrilhações, punções venosas, arteriais, torácicas, ...) são ofensas à integridade física, que o Código Penal ${ }^{1,16}$ aborda nos seguintes termos : (1)“...As intervenções e os tratamentos que, segundo o estado dos conhecimentos e da experiência da medicina, se mostrarem indicados e forem levados a cabo, de acordo com as leges artis, por um médico ou por outra pessoa legalmente autorizada, com intenção de prevenir, diagnosticar, debelar ou minorar doença, sofrimento, lesão ou fadiga corporal, ou perturbação mental, não se consideram ofensa à integridade física ${ }^{16}$; (2)- As pessoas indicadas no número anterior que, em vista das finalidades nele apontadas, realizarem intervenções ou tratamentos violando as leges artis e criarem, desse modo, um perigo para a vida ou perigo de grave ofensa para o corpo ou para a saúde são punidas ${ }^{16}$..."

Neste entendimento os procedimentos e tratamentos sem benefício expectável e com riscos associados, como é o caso da reanimação cardiorrespiratória não devem ser iniciados. ${ }^{1}$ As manobras de reanimação que não respeitem os preceitos referidos são ilícitas. ${ }^{16}$ A posição de princípio da Lei, neste caso, coincide com a perspetiva deontológica, moral e ética. ${ }^{1}$

O Código Deontológico da Ordem dos Médicos ${ }^{17}$ não tem preceitos especificamente dedicados a este assunto, mas o seu enquadramento aponta no mesmo sentido, designadamente:

“...Artigo 65. … O médico deve respeitar a dignidade do doente no momento do fim da vida ${ }^{17}$.

...Artigo $66^{\circ}$... Nas situações de doenças avançadas e progressivas cujos tratamentos não permitem reverter a sua evolução natural, o médico deve dirigir a sua ação para o bem-estar dos doentes, evitando a futilidade terapêutica, designadamente a utilização de meios de diagnóstico e terapêutica que podem, por si próprios, induzir mais sofrimento, sem que daí advenha qualquer benefício. 2 - Os cuidados paliativos, com o objetivo de minimizar o sofrimento e melhorar, tanto quanto possivel, a qualidade de vida dos doentes, constituem o padrão do tratamento nas situações a que o número anterior se refere. ${ }^{17}$

Artigo 67. ... 3 - O uso de meios extraordinários de manutenção de vida deve ser interrompido nos casos irrecuperáveis de prognóstico seguramente fatal e próximo, quando da continuação de tais terapêuticas não resulte benefício para o doente ${ }^{17}$ "

A ausência de DNR em doente que a deve ter é má prática.

\section{APLICAR A DNR}

Os relatos de que há serviços em que $85 \%$-98\% dos doentes que faleceram em ambiente hospitalar tinham DNR ${ }^{6,18}$ é indicador de boas práticas e abre boas expectativas sobre a possibilidade de aumentar essas boas práticas nos serviços em que aquelas ainda não existem. Nessas referências houve empenho em discutir as vantagens e inconvenientes da RCR, o que permitiu perceber que em caso de doença avançada com percurso antecipável para a morte, as intervenções cruentas e capazes e agravar o sofrimento de doentes e famílias foram evitadas. A DNR é uma dessas intervenções, que se deve centrar no melhor interesse do doente..$^{7,9-11,15}$

Assumidos os pressupostos da DNR esta deve ser formalizada em conformidade com as normas do registo clínico local, que deve incluir pelo menos:

a. Identificação completa do doente;

b. Identificação dos familiares / pessoas significativas e respetivos contactos;

c. Se o doente está capaz de participar na decisão;

d. Se há documentos / diretivas prévias expressando a vontade do doente sobre esta decisão;

e. Se houve um processo deliberativo prévio;

f. Quem participou no processo deliberativo e que argumentos foram analisados e contraditados;

g. Nome e funções dos membros da equipa que participaram na deliberação;

h. Nome e funções do sénior que assumiu a decisão e data da DNR;

i. Nos casos em que há formulário próprio é necessário preenchê-lo e assegurar que está disponível em local visível e de fácil acesso em caso de emergência.

Muitos dos doentes internados a quem foi prescrito a DNR têm alta. A transição para a comunidade (domicílio ou instituição) deve ser cuidadosamente preparada. Se os pressupostos para a DNR se mantêm, esta deve acompanhar formalmente a documentação e plano de cuidados, promovendo continuidade de cuidados. ${ }^{11}$ 


\section{Conclusão}

Se a situação do doente e/ou a evolução da doença antecipam a morte como desfecho inevitável, a prioridade é o acompanhamento e suporte em fim de vida, centrado no alívio dos sintomas, no conforto, na comunicação e na preservação da dignidade dessa pessoa em consonância com os seus desejos expressos. Os procedimentos e tratamentos sem benefício expectável, como pode ser o caso da RCR não devem ser iniciados.

\section{Responsabilidades Éticas}

Conflitos de Interesse: Os autores declaram a inexistência de conflitos de interesse na realização do presente trabalho.

Fontes de Financiamento: Não existiram fontes externas de financiamento para a realização deste artigo.

Proveniência e Revisão por Pares: Não comissionado; revisão externa por pares.

\section{Ethical Disclosures}

Conflicts of interest: The authors have no conflicts of interest to declare.

Financing Support: This work has not received any contribution, grant or scholarship.

Provenance and Peer Review: Not commissioned; externally peer reviewed.

(C) Autor (es) (ou seu (s) empregador (es)) 2019. Reutilização permitida de acordo com CC BY-NC. Nenhuma reutilização comercial.

(C) Author(s) (or their employer(s)) 2019. Re-use permitted under CC BYNC. No commercial re-use.

\section{Correspondence / Correspondência:}

António H. Carneiro - amhcarneiro@gmail.com

Departamento de Medicina, UCl e Urgência, Hospital da Luz - Arrábida

Vila Nova de Gaia, Portugal

Praceta de Henrique Moreira 150, 4400-346 Vila Nova de Gaia

Received / Recebido: 06/01/2020

Accepted / Aceite: 03/03/2020

Publicado / Published: 27 de Junho de 2020

\section{REFERÊNCIAS}

1. Carneiro AH, Carneiro R, Simões C-. Termos e conceitos na relação clínica. Rev Soc Port Med Interna. 2018;25: 157-64.

2. Boller M. Celebrating the 50th anniversary of cardiopulmonary resuscitation: from animals to humans... and back? J Vet Emerg Crit Care. 2010;20:5537. doi: 10.1111/j.1476-4431.2010.00593.x.

3. Kouwenhoven WB, Jude JR, Knickerbocker GG. Closed-chest cardiac massage. J Am Med Assoc. 1960; 173:1064-7.

4. Monsieurs KG, Nolan JP, Bossaert LL, Greif R, Maconochie IK. European Resuscitation Council Guidelines for Resuscitation 2015 Section 1. Executive summary. Resuscitation.2015; 95:1-80.

5. Valenzuela TD, Roe DJ, Nichol G, Clark LL, Spaite DW, Hardman RG. Outcomes of rapid defibrillation by security officers after cardiac arrest in casinos. N Engl J Med. 2000 ;343:1206-9.

6. Bossaert LL, Perkins GD, Askitopoulou H, Raffay VI, Greif R, from ethics of resuscitation and end-of-life decisions section Collaborators European Resuscitation Council Guidelines for Resuscitation 2015: Section 11. The ethics of resuscitation and end-of-life decisions. Resuscitation. 2015;95:302-11

7. Fritz Z, Slowthe AM, Perkins GD, Resuscitation policy should focus on the patient, not the decision. BMJ.2017;356:j813

8. Rosoff PM, Schneiderman LJ. Irrational Exuberance: Cardiopulmonary Resuscitation as Fetish. Am J Bioethics. 2017; 17: 26-34.

9. Scottish Government. Integrated Adult Policy... Published by the Scottish Government, May 2010, Reviewed August2016 Scottish Government, 2016. Do Not Attempt Cardiopulmonary Resuscitation: integrated adult policy in [accessed Dec 2019] Available from: http://www.gov.scot/resource/0050/00504976.pdf

10. Nevidjon B, Mayer D - "Death is not an option, how you die is - Reflections From a Career. Oncol Nursing Nurs Econ. 2012;30:148-52.

11. Carneiro R, Simões C, Carneiro AH. PIIC - Plano Individual e Integrado de Cuidados Rev Soc Port Med Interna. 2019;26: 147-52.

12. National Gold Standards Framework (GSF) Centre in End of Life Care - [accessed Dec 2019] Available from:http://www.goldstandardsframework.org. ukJ

13. Gracia D. Ethical case deliberation and decision making. Med Health Care Philosophy. 2003; 6: 227-33.

14. Gracia D. La Deliberación como método de la Ética, Diego Gracia in "Ética dos fundamentos à prática" Abril de 2017, pg 145-63 da Ética Aplicada, coleção coordenada por $\mathrm{M}^{\mathrm{a}}$ do Céu Patrão. Coimbra: Edições 70, grupo Almedina; 2017.

15. Cook D, Graeme R. Dying with Dignity in the Intensive Care Unit. New Engl J Med. 2014; 370:26.16. Código Penal, LIVRO II - Parte especial; TíTULO I - Dos crimes contra as pessoas - CAPÍTULO III - Dos crimes contra a integridade física - Artigo $150 .^{\circ}$ - Intervenções e tratamentos médico-cirúrgicos

17. Código deontológico da OM - Regulamento n. ${ }^{\circ} 707 / 2016$ Regulamento de Deontologia Médica in Diário da República, 2. ${ }^{a}$ série - N. ${ }^{\circ} 139-21$ de julho de 2016

18. Ananias J, Magalhães L, Ribeiro S, Ferreira B, Carneiro R, Martins A, Revisão da mortalidade de doentes cuidados pela Medicina Interna de um hospital privado. Comunicação Oral no $4^{\circ}$ Congresso Nacional de Medicina da Luz Saúde, 2016 